THE meeting of the Obstetrical Society on Wednesday evening promises to be one of much interest. Dr. Edis will read a paper on "The Forceps in Modern Midwifery," which is likely to give rise to discussion. Dr. Playfair will also contribute a paper on "Fibroid Tumour complicating Delivery," should time permit.

An Executive Committee meeting of the General Medical Council has been summoned. In addition to other pressing business we imagine that the subject of the time of the next meeting of the Council will be fixed.

\section{SANITARY CONDITION OF THE WAR OFFICE.}

THE Report of the Commission recently appointed to inquire into the sanitary state of the War Office is issued as we go to press. The whole of the War Office buildings, in Pall Mall, from basement to roof, were examined. The Commission, while satisfied that by no alterations can the building be rendered sanitarily satisfactory, desire to suggest that the following means should at once be adopted for the purpose of mitigating some of the present defects :-

" 1 . The closets in the area should be removed, with the exception of those needed by the families resident in the building, which should be thoroughly ventilated.

"2. The laundry should be removed.

" 3 . If it be impossible to remove the printing establishment, or greatly reduce the staff, ventilating shafts should be introduced into the second and third rooms, as has already been done in the îrst.

"4. The whole of the gas-burners throughout the building should have hcods and tubes.

" 5 . The condemned waterclosets ought to be removed at once.

" 6 . The waste pipes of the lavatories, and the overflow pipes of the cisterns, should terminate in the open air, and be cut off from all direct communication with drains. No traps will efficiently supply the place of open air termination.

"7. All taps communicating with cisterns which supply waterclosets should be removed, so that there may be no possibility of the water being used for drinking purposes.

" 8 . The building has been so cut about and altered that we cannot recommend any one system of ventilation as applicable to the whole office. The ventilation of each room and passage should at once be taken in hand, every case being treated specially. We would however recommend, in every instance, that the ventilators introduced should be of such a nature as to be beyond the control of the occupants of the room, and so constructed as not to create draughts.

"To render the air of the rooms less foul we advise that rooms be set apart for luncheons, and that a special hour be fixed for the meal. The windows of the rooms should be freely opened by a porter during the absence of the occupants.

"It must be borne in mind that these suggestions, if carried out, will, in our opinion, only mitigate evils, not remore them.

(Signed) "William JENNER, M.D.

"W. M. MuIR, M.D.

"Edward C. Seaton, M.D.

"A. B. Mitford,"

Manchester Medical Societr. - At the annual general meeting of this Society, held on January 10th, the following were elected office bearers for 1877:- President: Dr. Ransome. Vice-Presidents: Dr. Leech, Dr. Little, Dr. Lloyd Roberts, Mr. Windsor. Hon. Secretary: Mr. Walter Whitehead. Hon. Treasurer: Dr. Thorburn. Hon. Librarian: Mr. Cullingworth. Committee : Dr. Bird, Dr. Borchardt, Mr. Broadbent, Mr. Bradley, Mr. S. Buckley, Dr. Dreschfeld, Professor Gamgee, Mr. Galt, Mr. Heath, Mr. Jones, Mr. Pinder, Dr. Ross. Auditors: Mr. A. Boutflower, Dr. Maccall.

\title{
Correspondence.
}

"Audi alteram partem."

\section{ON POISONING BY COPPER.}

\section{To the Editor of The LanceT.}

SiR,-Having, in the course of some recent inquiries into poisoning by copper, come across certain facts of special interest with which I was not previously arquainted, and which, if I am not mistaken, have not been noticed by English writers on toxicology, I should be glad if you could find place for them in your columns.

Acute Poisoning by Copper.

1. In the second volume of the "Medical Observations and Inquiries, by a Society of Physicians in London," published 1764, I find a letter from Mr. James Ramsay, surgeon, on "Copper Vessels," addressed to George Macaulay, M.D., and read at the Society, Outober 2ud, 1758. I will give the substance of this communication in as few words as I can.

On the 2nd Sept., 1757, William Carlile, aged fourteen, was suddenly seized with convulsions, and fell down on deck insensible. For a quarter of an hour he remained with eyes fixed, face convulsed, and head awry. Under the influence of hartshorn be became a little sensible, and soon after had a slight anodyne, which he immediately threw up with a large quantity of yellow bile. A messmate here recollected that he had seen him at dinner eating peas from the bottom and sides of the large copper kettle. He was then ordered an emetic, but before it could be given fell asleep. During the right he was frequently convulsed, cried out like a child, talked incoherently, and struggled so that two men could scarce hold him. In the morning he had pains in his bones and head, and nausea. An emetic of ipecacuanha was therefore given him, followed by an anodyne, and in two days he was quite well. Upon inspecting the kettle, a good deal of verdigris was found at the corners of it.

Six days after this Mr. Ramsay was summoned on board the Vestal frigate to consult with two other surgeons "about some people that were taken suddenly ill of a very surprising disorder." On the 6th September (two days previously) one man was seized in an instant with dulness, stupidity, and headache. He fell down, and struggled so hard that it required six men to hold him; soon became delirious, and behaved in the most extravagant manner. The next day (the 7th) reveral more were seized, and on the $8 \mathrm{th}$ sixteen more. They were all at times outrageous and mad, struggling violently, and snapping with their teeth at those who held them. One fancied himself a captain, and gave orders accordingly; a second called out "ground ivy to sell"; a third, "old chairs to mend"; one spat in your face, and laughed heartily; one was merry, and sang; another surly and ill-natured; another moped in a corner, stupid and insensible. All had luc d intervals, and complained of pains in their bones and of headache. The pulse, during the fit, was full, quick, and strong; but it became soft on a sweat breaking out. 'Their eyes were inflamed, their looks wild, their speech incoherent, and thag slept little. None complained of gripes, and few of nausea. The fits returned after various intervals and more than once, and seem to have been rendered less violent by bleeding. Vomiting did not afford any immediate relief. After the 8th there were no more seizures, and all recovered in three or four days. The ship was large, airy, newly built, and hitherto very healthy. The men were served with fresh meat, and the beer and provisions were good. The seizures chiefly took place after dinner. On inspecting the kettles, "nothing remarkable was found in them."

Again, under date November 27, Mr. Ramsay witnesses " the like malady," "attended with the same odd symptoms," on board the Adventure, armed ship. The surgeon found the coppers very foul; but, upon remedying that fault, the disease stopped. About fifteen persons were seized with it.

Mr. Ramsay attributed these strange symptoms to verdigris; adding, that " though in the vessel the fault was not so very apparent, yet the disease, stopping all of a 